
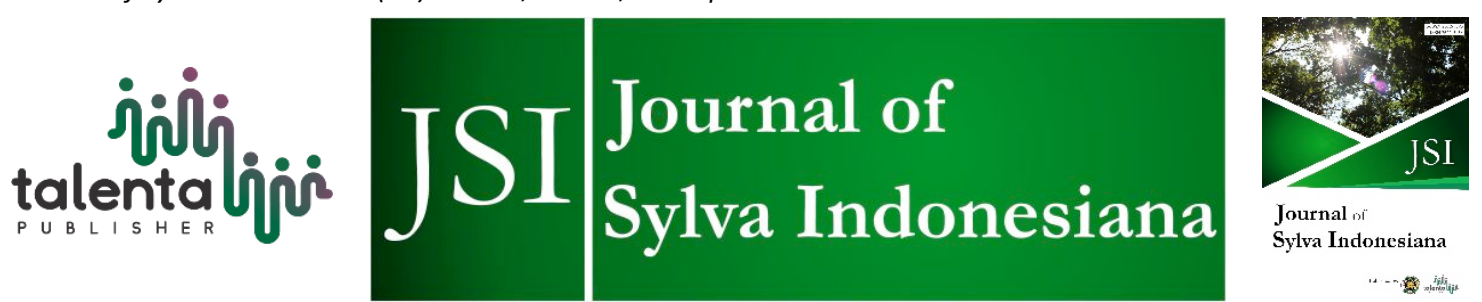

\title{
Morphological Diversity of Mindi (Melia azedarach) from Agroforestry System in North Sumatra, Indonesia
}

\author{
Ridahati Rambey ${ }^{1,2} *$, Arida Susilowati, ${ }^{1,2}$, and Nelly Anna ${ }^{1}$ \\ ${ }^{I}$ Faculty of Forestry, Universitas Sumatera Utara, North Sumatra, Indonesia. \\ ${ }_{2}^{2}$ JATI-Sumatran Forestry Analysis Study Center, North Sumatra, Indonesia
}

\begin{abstract}
Mindi (Melia azedarach) is a fast-growing woody plant with potential for community forest development. Mindi wood is used to furniture material, parquet, fancy plywood, and fancy laminated veneer, and it is also exported. Although the community forest in Deli Serdang Regency is established as a seed source for mindi in North Sumatra, information on its diversity is still lacking. The aim of this research was to get information about morphological differentiation of mindi in Deli Serdang Regency. Direct observation and measurement on morphological and growth character of mindi had been conducted in three populations of community forest in Deli Serdang Regency. Those were Percut Sei Tuan population, Biru-Biru population, and Pancur Batu population. The result showed that of 19 observed morphological characters, there were two characters: number of leave and fruit weight able to differentiate the populations-individual tree from three population clustering into three groups. The first cluster consists of 35 individual trees from Percut Sei Tuan (7 trees), Biru-Biru (12 trees), and Pancur Batu (16 trees). The second cluster consist of 24 trees originated from Percut Sei Tuan (13 trees), Biru-Biru ( 8 trees), and Pancur Batu ( 3 trees). A third cluster consists of one tree from Pancur Batu.
\end{abstract}

Keyword: Agroforestry, Melia azedarach, Morphological Diversity, North Sumatra

Received 29 January 2021 | Revised 2 March 2021 | Accepted 5 March 2021

\section{Introduction}

Melia azedarach, also known as mindi, is a small to medium deciduous tree with a spreading crown and irregularly branching that may reach a height of $45 \mathrm{~m}$. It has a bole fluted below when old, up to $30-60 \mathrm{~cm}$ in diameter, and is one of the most important trees in the Meliaceae family [1]. Mindi has a wide range distribution. Can grow well from the lowlands to the highlands at an altitude of $0-1200 \mathrm{mdpl}$, at a minimum temperature of $-5{ }^{\circ} \mathrm{C}$ and a maximum temperature of $39^{\circ} \mathrm{C}$, with an annual rainfall of $600-2000 \mathrm{~mm}$. Mindi was an indigenous species

*Corresponding author at: Faculty of Forestry, Universitas Sumatera Utara, Jl. Tridharma Ujung No.1, Kampus USU Medan 20155, North Sumatera, Indonesia.

E-mail address: ridahati.2017@gmail.com

Published by Talenta Publisher

p-ISSN: 2622-5093 e-ISSN: 2622-5158 DOI: 10.32734/jsi.v4i02.5520

Journal Homepage: http://jsi.usu.ac.id 
of South Asia, but it also has a wide natural distribution in and around Japan, as well as Indonesia [2].

Mindi trees are well-adapted and fast-growing trees with several uses for their wood and medicinal properties [3]. Meliacin, a glycopeptide derived from the plant's leaves and roots, was already farmacologically evaluated for its ability to prevent virus DNA and RNA, particularly folio virus proliferation [4]. Because of its termite resistance, the wood is often utilized for carpentry, furniture, and other products [5].

Morphological information can be utilized to determine a species' conservation actions. We use morphological characters in this study to show information on this species, especially the species preference. In this study, measurements of morphological characters were carried out to distinguish thoughts in each population. Morphological characterization plays an important role in systematic biology [8]. Unclear information and people's preferences to cultivate only certain species are factors that trigger the loss of a species [9]. Therefore, a study was conducted to obtain information about the morphological differentiation of mindi in Deli Serdang Regency.

\section{Research Method}

The method of observing morphological characters in the field is carried out directly. Leaf and fruit samples were used as representatives of the two characters. Percut Sei Tuan, Pancur Batu, and Biru-Biru, all part of the mindi agroforestry system, were chosen as research sites.

The main Petiole length, minor Petiole length, leaf number, leaflet number in each minor Petiole, number of Petiolee, leaf length, leaf width, leaflet lenght, leaflet vein, number of veination, number of outher vein, fruit diameter, fruit length, and fruit weight were among the 19 leaf and fruit characters used to differentiate mindi. Identification and determination referred to [10] and [11].

Fruits and leaf organs were used to plant samples. Direct observation was carried out on a specific part of the speciment in great detail. Using the Microsoft Excel application, the quantitative and qualitative data of morphological characteristics observed were converted into binary score data and organized into a data matrix. To obtain a phylogenetic dendogram, the data matrix was utilized to evaluate sample clustering using the SAHN (Sequential Agglomerative Hirearchical and Nested Clustering) technique with the UPGMA (Unweighted Pair Group Method Using Average) method with the NTSYS software. 


\section{Results and Discussion}

\subsection{Agroforestry pattern of mindi in research location}

Agroforestry is the science and practice of integrating trees with agricultural plants and livestock to manage land use [12]. Due to its rapid multifunctional, growing species, and deciduous behavior, Mindi is a desirable agroforestry plant. People in Deli serdang are planting mindi in a different pattern, such bunds along the coast, ponds, and cacao shade trees. Mindi is commonly planted in coastal areas as buffers, communal ponds, and wet rice fields with a 0-3 mdpl altitude among the Percut Sei Tuan population. In this population, the seeds for mindi cultivation came from natural regeneration by collecting seedlings under the parent trees. Because of thicker seed coat, which acts as a barrier to mindi germination, the farmer is still unwilling to propagate artificially.

Mindi trees are commonly planted as buffer trees or intercropping with cocoa in Biru-Biru plantations with an agroforestry method. Mindi has a light canopy, making it an ideal choice for a shade tree for preserving annual crops. Mindi was discovered in Selaawi Village, West Java, as a mixed tree with tea, coffee, and seasonal plants [7]. Big mindi and small mindi can also be found at Selaawi Village, West Java. In Pancur Batu, mindi is cultivated using an agroforestry pattern as a land border. Mature trees with a diameter of $20 \mathrm{~cm}$ are offered straight to the buyer for use in furniture or construction. Table 1 shows the agroforestry pattern in the research area.

Table 1 Agroforestry pattern in Deli Serdang

\begin{tabular}{|c|c|c|c|c|c|c|c|}
\hline No Population & Coordinate & $\begin{array}{c}\text { Altitude } \\
\text { (masl) }\end{array}$ & Planting pattern & $\begin{array}{l}\text { Tree } \\
\text { Age } \\
\text { (year) }\end{array}$ & $\begin{array}{l}\text { Height } \\
\text { average } \\
(\mathrm{m})\end{array}$ & $\begin{array}{c}\text { Clear bole } \\
\text { Average } \\
(\mathrm{m})\end{array}$ & $\begin{array}{c}\text { Diameter } \\
\text { average } \\
\left(\mathrm{cm}^{2}\right)\end{array}$ \\
\hline $\begin{array}{ll}1 & \begin{array}{l}\text { Percut Sei } \\
\text { Tuan }\end{array}\end{array}$ & $\begin{array}{l}\text { N } 03.71609^{\circ} \\
\text { E } 098.78577^{\circ}\end{array}$ & 0 & $\begin{array}{l}\text { cultivate in } \\
\text { coastal boundary }\end{array}$ & 6 & 14.51 & 7.87 & 25.64 \\
\hline 2 Biru-Biru & $\begin{array}{l}\text { N 03.39371 } \\
\text { E 098.66812 }\end{array}$ & 150 & mixed with cocoa & 12 & 20.77 & 13.17 & 29.10 \\
\hline 3 Pancur Batu & $\begin{array}{l}\text { N 03.506520 } \\
\text { E 098.55361 }\end{array}$ & 83 & $\begin{array}{l}\text { mixed with } \\
\text { annual crop }\end{array}$ & 7 & 16.00 & 7.40 & 21.24 \\
\hline
\end{tabular}

The sourced seedlings are likely to have an important role in the future tree cover on farms. As a result, the genetic composition of agroforestry ecosystems has an influence on their production and long-term sustainability. Farmer in Deli Serdang collected seedlings from a particular seed stand and prefer to cultivate large-sized seeds since they grow faster than small-sized seeds for practical reasons. This preference, as well as conventional cultivation methods, may threaten the genetic material of mindi in the area. Because collections practice was the most obvious limiting bottleneck in delivering high levels of genetic diversity. As a result, in order to avoid genetic loss, an improved propagation strategy is still required at this site.

\subsection{Morphological character of mindi}

Figure 1 shows the morphological performance of observed mindi fruit, seed, bark, and tree in three populations. Mindi's performance at the research site was comparable to that described in 
[13]. The Mindi tree may grow to be 45 metres high. When young, its bark is smooth and greenish-brown, and as it ages, it becomes grey and fissured (1c). Mindi fruit is a small yellow drupe that is roughly spherical and is approximately $15 \mathrm{~mm}$ in diameter. It is smooth and shrivelled, with a slightly meaty texture (1a). The seed is oblongoid (1b), approximately $3,5 \mathrm{~mm} \times 1,6 \mathrm{~mm}$, smooth, brown, and coated in pulp.

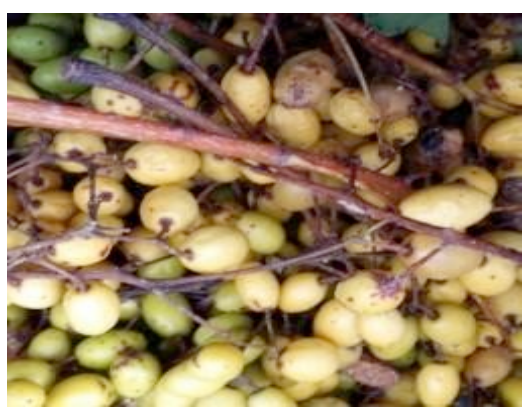

a. Fresh fruit

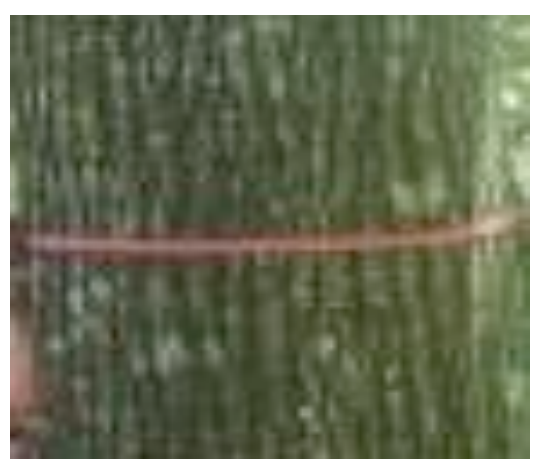

c. Bark fissure on mindi

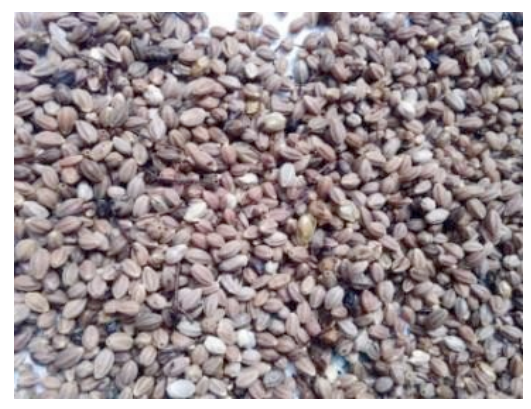

b. Extracted seed

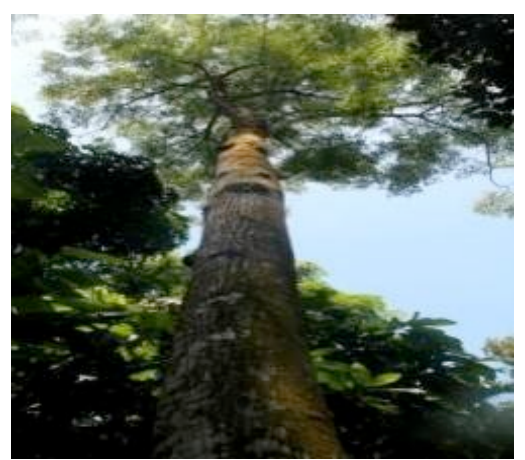

d. Mindi tree

Figure 1 Morphological performance of fruit (a), seed (b), bark (c), and tree (d) observation on Petiole character, fruit and leaf of mindi in three population presented in Table 2.

The number of leaves and fruit weight characters may be utilized to differentiate each population based on statistical analysis. Mindi leaves are unusual bipinnately compound, measuring 9-48 cm from primary Petiole basal to leaflets tip, with an average length of 48.65 $\mathrm{cm}$ in Percut Sei Tuan, $48.43 \mathrm{~cm}$ in SiBiru-Biru, and $43.32 \mathrm{~cm}$ in Pancur Batu. When compared to other petioles, Percut Sei Tuan's petiole is the longest. The average petiole length was 9.92 $\mathrm{cm}$ for Percut Sei Tuan, $9.91 \mathrm{~cm}$ for Biru-Biru, and $12.88 \mathrm{~cm}$ for Pancur Batu, with the average being $11.52 \mathrm{~cm}$ for Percut Sei Tuan, $9.91 \mathrm{~cm}$ for Biru-Biru, and $12.88 \mathrm{~cm}$ for Pancur Batu. The average for all leaflets in the main Petiole was 75.75 for Percut Sei Tuan, 99.33 for Biru-Biru, and 94.76 for Pancur Batu/main Petiole). Each major Petiole has 9-16 side-divided Petioles and 8-14 minor leaflets (on average 8.35 leaflets/side-divided Petiole for Percut Sei Tuan, 9.26 for Biru-Biru, and 13.62 for Pancur Batu). The average leaflet length and thickness for Percut Sei Tuan were 5.81 and $2.36 \mathrm{~cm}, 6.39$ and $2.21 \mathrm{~cm}$ for Biru-Biru, and 7.25 and $2.69 \mathrm{~cm}$ for Pancur Batu. 
Table 2 Morphological observation of mindi in each population

\begin{tabular}{|c|c|c|c|c|c|c|}
\hline No & Morphological Character & $\begin{array}{l}\text { Percut Sei } \\
\text { Tuan }\end{array}$ & Biru-Biru & $\begin{array}{c}\text { Pancur } \\
\text { Batu }\end{array}$ & $\begin{array}{c}\text { Sig. } \\
(P<0.05)\end{array}$ & Note \\
\hline 1 & Main Petiole length $(\mathrm{cm})$ & 48.65 & 48.43 & 43.32 & 0.540 & Ns \\
\hline 2 & Side Petiole length $(\mathrm{cm})$ & 11.52 & 9.91 & 12.88 & 0.662 & Ns \\
\hline 3 & Side Petiole number & 9.42 & 10.92 & 15.49 & 0.207 & Ns \\
\hline 4 & Leaflet number & 75.75 & 99.33 & 94.76 & 0.000 & S \\
\hline 5 & Minor leaflet number & 8.35 & 9.26 & 13.62 & 0.292 & Ns \\
\hline 6 & Leaflet length $(\mathrm{cm})$ & 5.81 & 6.39 & 7.25 & 0.737 & Ns \\
\hline 7 & Leaflet width $(\mathrm{cm})$ & 2.36 & 2.21 & 2.69 & 0.789 & Ns \\
\hline 8 & Number of veination & 21.08 & 19.94 & 26.77 & 0.425 & Ns \\
\hline 9 & Petiole diameters $(\mathrm{cm})$ & 0.90 & 0.83 & 0.95 & 0.836 & Ns \\
\hline 10 & Leaf distance $(\mathrm{cm})$ & 2.72 & 2.27 & 3.26 & 0.486 & Ns \\
\hline 11 & $\begin{array}{l}\text { Distance between minor } \\
\text { Leaflet }(\mathrm{cm})\end{array}$ & 7.021 & 5.74 & 8.17 & 0.468 & Ns \\
\hline 12 & $\begin{array}{l}\text { Average of minor leaflet } \\
\text { Petiole }(\mathrm{cm})\end{array}$ & 0.791 & 0.65 & 0.77 & 0.742 & Ns \\
\hline 13 & Wide to leaf angle $(\mathrm{cm})$ & 1.07 & 1.08 & 1.40 & 0.601 & Ns \\
\hline 14 & Average lenght of Petiole & 2.81 & 3.04 & 3.62 & 0.656 & Ns \\
\hline 15 & Number of outer vein $(\mathrm{cm})$ & 15.56 & 18.57 & 25.87 & 0.137 & Ns \\
\hline 16 & Leaf area $(\mathrm{cm})$ & 8.43 & 7.27 & 7.67 & 0.824 & Ns \\
\hline 17 & Fruit diameter $(\mathrm{cm})$ & 1.16 & 0.98 & 1.63 & 0.316 & Ns \\
\hline 18 & Fruit length $(\mathrm{cm})$ & 1.544 & 1.33 & 2.23 & 0.342 & Ns \\
\hline 19 & Fruit weight (g) & 1.195 & 1.10 & 0.93 & 0.004 & S \\
\hline
\end{tabular}

Note: Sig. $(\mathrm{P}<0.05)=$ Significant $(\mathrm{P}<0.05)$, Significant $\mathrm{S}=$ Significant, NS: Non Significant

Mindi fruits weighed an average of $1.195 \mathrm{~g}$ in the Percut population, $1.10 \mathrm{~g}$ in the Biru-Biru population, and $0.93 \mathrm{~g}$ in the Pancur Batu population. This result was consistent with earlier study [14], which revealed that the weight of mindi fruit varied between 1.03-2.40 g, with an average of $1.55 \mathrm{~g}$. We create a dendrogram based on this information to classify the mindi according to morphological observations. In contrast to the diversity coefficients, which were used to assess the degree of inter species differences or population on specified features [9], the degree of similarity between species or populations. Figure 2 shows an dendrogram of the Mindi population.

Individual tree from three populations grouped into three clusters. The first big cluster consist 35 individual trees from Percut Sei Tuan (7 trees), Biru-Biru (12 trees) and Pancur Batu (16 trees). The second big cluster consist of 24 tree originated from Percut Sei Tuan (13 trees), Sibiru- biru (8 trees) and Pancur Batu ( 3 trees). A third clusters consist of one tree from Pancur Batu. The morphological diversity of a plant can be caused by environmental or genetic factors or interactions of both factors. 


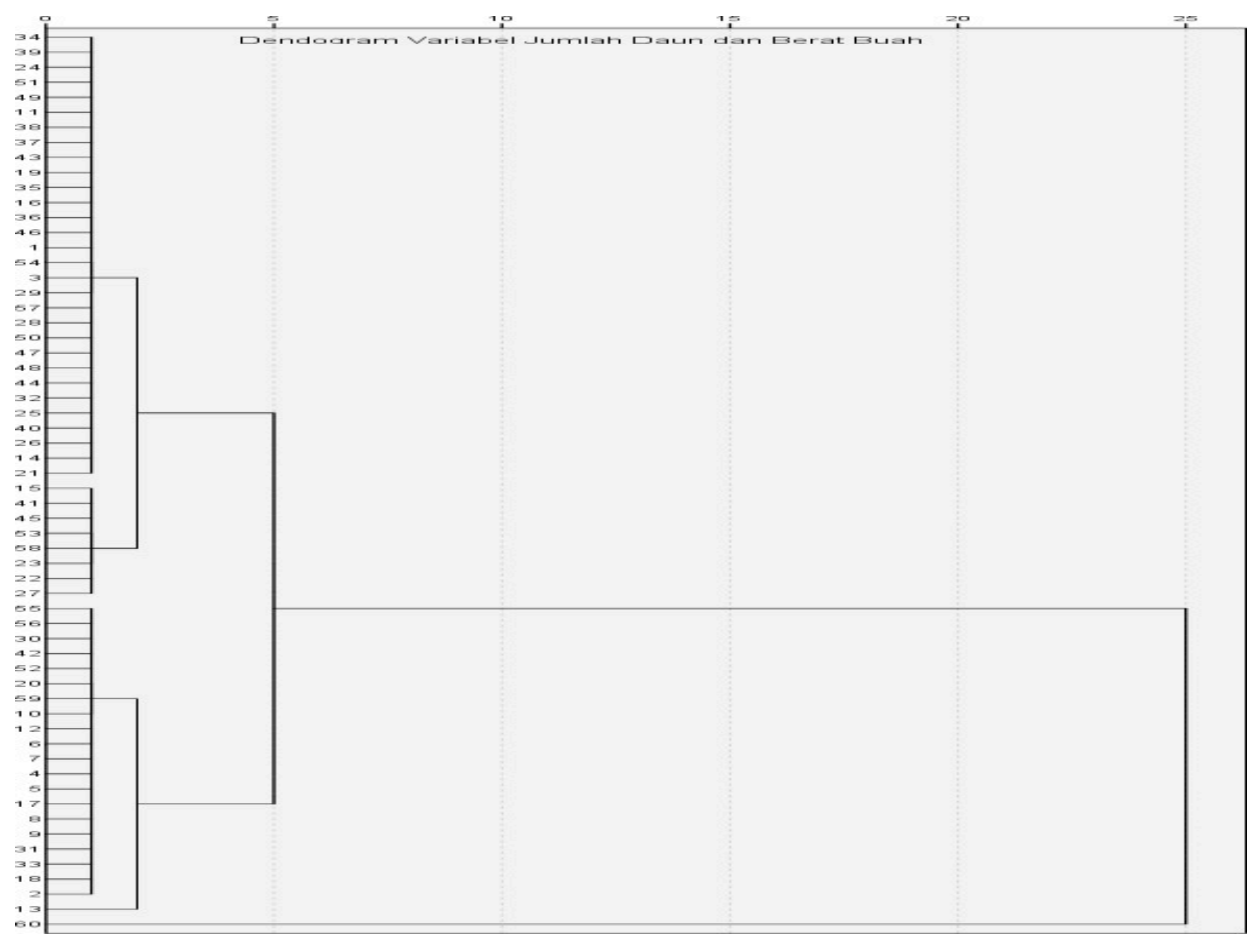

Figure 2 Grouping pattern of individual mindi tree in three population

Environmental variables interact with plants both biotically and abiotically, whereas genetic factors are those passed down from one generation to the offspring. Micro and macros climate (temperature, humidity, rainfall), altitude, and site conditions are all biotic environmental variables that impact a plant's morphological condition [15]. However, because of the differences in concept review and subjectivity across observers, distinct dendrogram patterns and categorization models may develop, regardless of the fact that they are fairly similar in general. The higher the validity, the better a character's ability as a distinguishing trait, the more the ability to detect relatedness levels [16].

\section{Conclussion}

We found that the mindi diversity in three populations was quite high, based on the morphological data. Leaflet number and fruit weight are two of the 19 Mindi characteristics that may be employed to differentiate each population. The individual trees of the population were classified into tree clusters using dendrogram analysis, with the first and second clusters consisting of some individuals from three populations, and the third cluster consisting of one tree from the Pancur Batu population.

\section{Acknowledgement}

We are grateful to Rector Universitas Sumatera Utara for generous help to our research funding through TALENTA USU 2016 No: 6051/UN5.1/R/PPM/2016. 


\section{REFERENCES}

[1] Wardhani M. Mindi: Morphology, distribution and place of growth, Forest Research and Development Agency, Jakarta, 2001.

[2] Chiefella I.C., Amanda H.F., Diego H.R. "Chilean," J. Agric. Res vol. 69, no. 1. 2009.

[3] Sharma D, Paul Y. Journal of Applied Pharmaceutical Science, vol.3, no. 12, pp. 133-138. 2013.

[4] Sulastiningsih IM, Hadjib N. "The use of midi wood (Melia azedarach L.) Juhany LI 2011," Turk J Agric For, vol. 35, pp. 165-171. 2001.

[5] World Agroforestry Centre, A Tree Species Reference and Selection Guide, 2006. [Online]

[6] De Foresta H, Kusworo A, Michon G, Djatmiko A. When a garden looks like a forest: typical Indonesian agroforest - Society contribution for sustainable development (in Indonesian), International Center for Research in Agroforestry, Bogor, 2000.

[7] Rambey R. "Study of agroforestry mindi planting pattern (Melia dubia cavanilles) in Selaawi Village, Garut District, West Java Province," IOP Conference Series: Earth and Environmental Science. 2019.

[8] Rahayu S.E. and Handayani S. Vis Vitalis, vol. 1, no. 20, pp. 29-44. 2008.

[9] Susilowati A., Kholibrina C.R, Rachmat H.H, Munthe M.A. IOP Conf. Ser.: Earth Environ. Sci. 122 012062. 2018.

[10] Steenis V. Flora Malesiana vol. 1, no. 42. 1953.

[11] Tjitrosoepomo G. Plant Morphology, Gajah Mada University Press, Yogyakarta, 1990.

[12] Patil S.J, Muntanal S.M, Patil H.Y. Karnataka J Agric Sci. vol. 25, no. 4, pp. 460462. 2011.

[13] Orwa C, Jamanadas RH, Kindt R, Matua A, Simon A. Agroforestry database, World Agroforestry Center, Bogor, 2009.

[14] Cavosoglu A, Solusoglu M. "Phenological and Morphological Characteristics of Melia azedarach L. in Kocaeli City in Turkey," J Horticulture vol. 59. 2015.

[15] Bramasto Y, Sudrajat DJ, Rustam EY. Pros Sem Nas Masy Biodiv Indon, vol. 1, no. 6. 2015.

[16] Suratman, Dwi P, Setyawan AD. J Biodiversitas vol. 12. 2011. 